\title{
From the office skyscraper to the residential tower: the case of the Vistamar tower in Alicante, 1962-1965
}

\author{
Justo Oliva-Meyer ${ }^{10000-0002-4991-8969]}$, Andrés Martínez-Medina ${ }^{1[0000-0002-5309-9310]}$ \\ and Marco Lucchini ${ }^{2[0000-0001-8051-3313] ~}$ \\ ${ }^{1}$ DEGCP, Universidad de Alicante, ESP \\ ${ }^{2}$ DATSU, Politécnico di Milano, IT \\ justo.oliva@ua.es; andresm.medina@ua.es; \\ marco.lucchini@polimi.it
}

\begin{abstract}
In 1959, Guardiola Gaya (1927-2005) arrived in Alicante from the Perpiñá studio and designed two touristic development projects. The enclave of La Albufereta is projected with models, due to the rugged relief, whose epicenter is the Vistamar tower (1962-65). It is probably the first freestanding residential skyscraper in Spain, close to 100 meters thanks to a steel structure, and offering panoramic views over the horizon. This volume, with its abstract lenticular plan geometry, presents achievements typical of the modern movement: the isolated prism as a metaphor of a typical ship, the functional asymmetry, the prolonged living room opening onto the terraces, as well as its austere materiality. Many of these finds are reinterpretations of the traditions of the Mediterranean habitat. Of special interest are the connections that this landmark establishes with the cultured architecture disseminated in the mass media, in particular, with the Pirelli tower (1952-61, Milan) by Ponti's studio that extends its influence to the Banco Atlántico (1965-67, Barcelona) from the Mitjans studio. These towers can be read as 'functional monuments' of the European metropolises. This text explores the transition from the office skyscraper to the residential tower in this case with this slender model.
\end{abstract}

Keywords: Office Skyscrapers, Pirelli and Ponti, Residential Tower, Residential Touristic Architecture, Juan Guardiola Gaya, Vistamar Alicante.

"Les gratte-ciel de New York sont trop petits et trop nombreux. (...) Ils sont la preuve que tout peut déjà être entrepris selon (...) un plan symphonique: extension et hauteur. Son histoire est mêlée de questions d'utilité et de vanité. (...) couvrent l'horizon. Je n'imaginais pas qu'il y en avait autant. (...) Les gratte-ciel, je dois l'avouer, sont ici un accident d'architecture."

Le Corbusier, 1936

\section{From the American to the European skyscraper: from technical progress to aesthetic concept First Section}

In $1850 \mathrm{~J}$. Bogardus patented a system of precast cast iron pillars and beams for construction that defined a spatial grid, clearly evidenced in the plan and section plans of 
his projects (Fig. 1a). This new structure was an immediate success and was used in office and commercial buildings. Two years later, E.G. Otis invented the elevator that would be applied in 1857 in New York. However, between these technical achievements and the birth of the skyscrapers in Chicago, after the fire of 1871 , there is no linear relationship between time and the increase in height. In the 'downtown' of this city so many companies were concentrated that the price of the plot increased, as L.H. Sullivan related [01], causing buildings to triple in height to 16 stories $(50 \mathrm{~m})$.

The term 'skyscraper' (literally: scrape the sky) was applied for the first time to the Mountak Building of 1881 [02, p.23] (Fig. 1b). Almost all of the 'Chicago School' skyscrapers were office buildings back-to-back with their neighbours within city plot limits; its spacious commercial 'halls' on the lower floors - not all - were perceived as covered public squares, which gave a break to the streets and which have been interpreted as a "city within a city" [03, p.62]. A new architectural species had been born, according to Sullivan's famous statement in 1896: "form ever follows function" —of Darwinian inspiration-, which multiplied the available land by repeating upwards an advance of the 'free plan' and whose spine was the core of elevators. This dizzying evolution was a reflection of pragmatism, a trend founded by the philosopher C.S. Peirce (1839-1914), who focused his interest on facts and action [04, pp. 89-92].
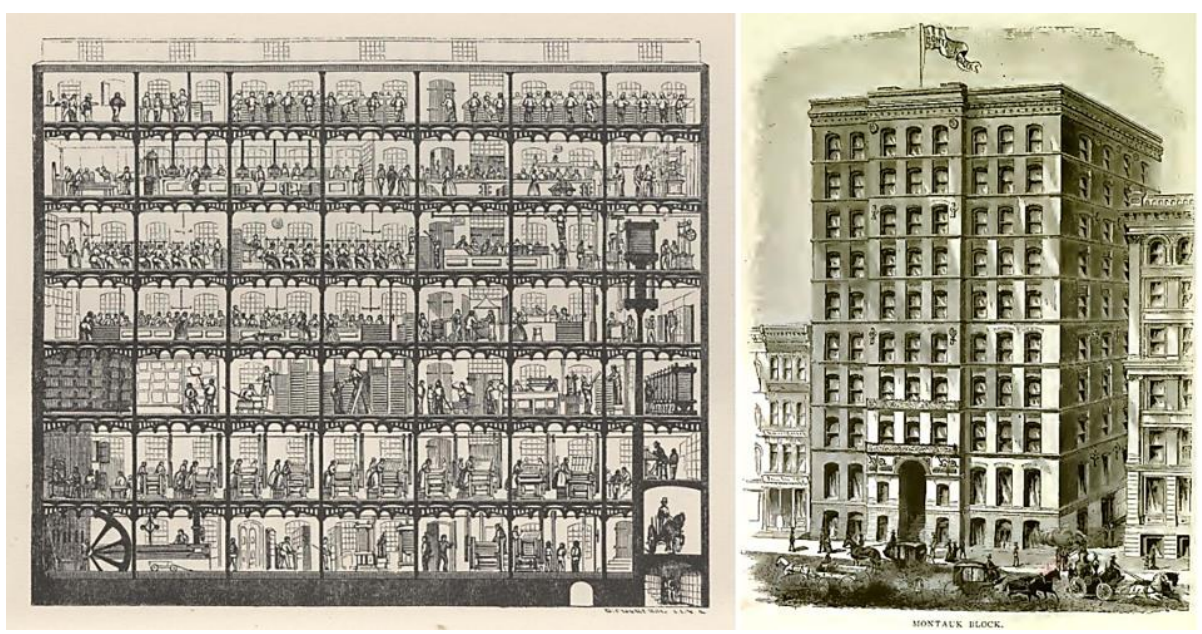

Fig. 1. (a): Sectional view of the Cliff Street Building, New York, 1855, James Bogardus [05]; (b) Montauk Building, Chicago, 1881-82 Burnham \& Root (Public Domain).

This first generation, exclusively for tertiary use embedded in the plots, would have its own route in New York where, since the beginning of the 20th century and, thanks to technical advances (strength of steel, calculation of structures and speed of elevators), it tripled once again its height $(169 \mathrm{~m})$ in the Equitable Building of 1915. This immense volume prevented sunlight and air circulation from reaching the streets of the financial district of Manhattan and reduced the rents in the surroundings [06, p. 
107]. To avoid this damage, the 'Zoning Resolution' of 1916 was approved, which forced setbacks in the solid building proportional to its elevation, although no maximum height was set, giving way to a second generation of skyscrapers, now staggered. This new type would reach its zenith with the Chrysler and the Empire State $(380 \mathrm{~m})$, which doubled in height again until they touched the clouds. This record coincided with the crash of 1929 and ended up outlining the unique 'skyline' of sharp towers of the already cinematographic metropolis. This new generation, capable of bringing together and distributing all kinds of tertiary uses (including health, leisure and private clubs, such as the Down Athletic Club, 1930), had become a social condenser, a microcosm that reproduced the world [06, pp. 81-159]. In addition, together with hotel destination, around 1930 the first residential skyscrapers appeared: the panoramic views from the top were a privilege.

A good example of the evolution of this type would be the proposals submitted for the Chicago Tribune competition in 1922 in which this specimen appeared as a free, slender and stepped as it grew, with a tendency to occupy the entire block. Second place went to Saarinen Sr.'s project, a stepped prism that Sullivan himself would praise, while lamenting the historicist-biased first prize. Many European architects sent drawings to this invitation and almost all of them constituted experiments in volume (Fig. 2), thus fulfilling the objective of the competition that was pursuing the 'most beautiful' skyscraper. Skyscrapers had not yet been built in Europe, but their exploration had already begun. The approach, typical of the avant-garde, focused on the image and its visual impact rather than on the interior of the form. Mies van der Rohe designed two in Berlin in 1921 and 1922: their respective frames were forests of metal, so it can be seen in their perspectives and models, because their envelopes were expressionist glass skins that reflected the light.
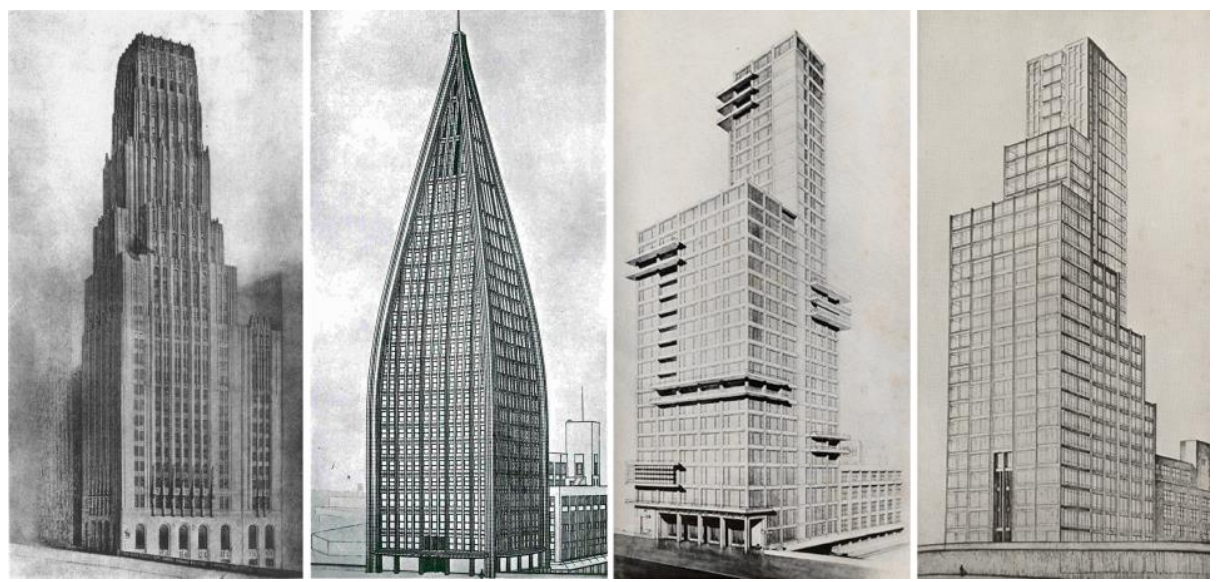

Fig. 2. Four perspectives of projects by European architects submitted to the Chicago Tribune competition, 1922; (from left to right): E. Saarinen (2nd prize); B. Taut with W. Gunther \& K. Schutz; W. Gropius \& A. Meyer; M. Taut (Public Domain). 
But it would be Le Corbusier who would shift the conceptual interest from the isolated object - skyscrapers - to the urban complex - city - and, from here, to the metropolitan skyline, in order to return to the beginning. In fact, in 1922, Le Corbusier designed the Ville Contemporaine, with 24 skyscrapers of 60 floors in its central area: vertical and without cutbacks. Their structure was of steel: "a skeleton woven like a filigree in the sky (...): clear and free", and its facades "a film of glass" [07, p. 82]. In this decade, the Swiss explored various types of skyscrapers, always as plumb towers with different plan solutions, as well as residential height blocks. In 1929 he visited South America where, for Buenos Aires, he proposed a group of towers shining at night in dialogue with the horizontal of the sea; the twinkling lights of the Manhattan skyscrapers fascinated him: "A million windows in the sky. This is where the magic show begins" [07, p. 126]. The third generation of skyscrapers with sharp prisms was in the making, which the master confirmed after visiting Rockefeller Center.

Between 1930 and 1942 Le Corbusier worked on the Obus plan for Algiers, an urban plan that was to be modified. It contained 'megastructures' and skyscrapers; in fact, in the period 1931-1934 a duplicated skyscraper with a hexagonal plan already appeared (Fig. 3a). After visiting New York in 1936, he changed his point of view on the number and density of skyscrapers because, among other issues, they blocked out the horizon [07, p. 125]. This thought led him to conclude that "In Algiers a single skyscraper will suffice" [07, p. 100], and so it was: raised from the ground with pilotis as he drew all his architecture.

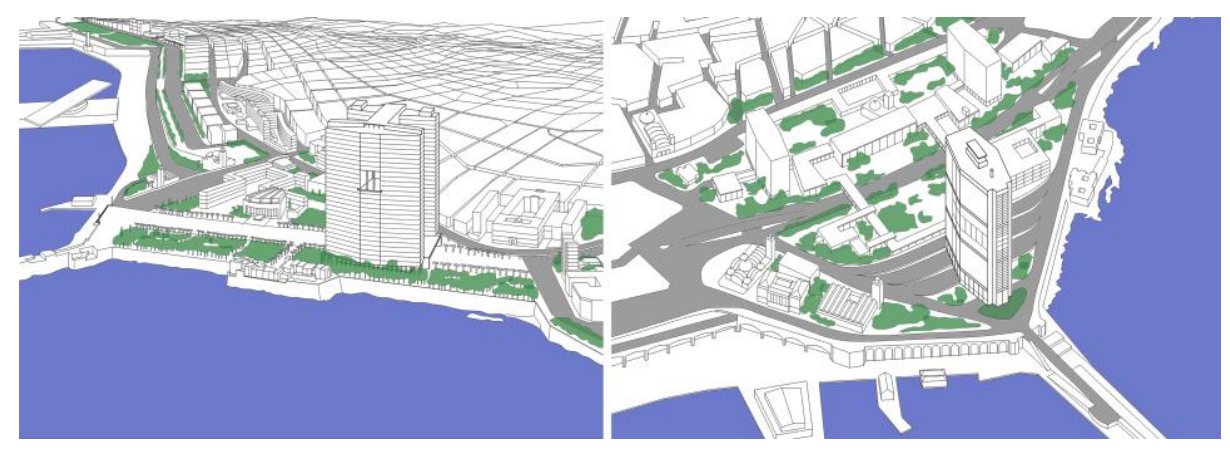

Fig. 3. Plan Obus, 1930-1942, Le Corbusier. Volume diagrams of the Naval Zone at Algiers (Authors, 2020), (a): 1931-1934, Proyect C, with double hexagonal skyscraper, parallel to the coast. (b): 1938, skyscraper with a hexagonal plan, perpendicular to the sea.

Upon his return, in the project for the Naval Zone of Algiers, in 1938, he placed only one vertical landmark with a hexagonal plan contrasting with the blue background of the Mediterranean, looking out over the sea from its two opposing facades, and which emerged as a visual icon for the city and its coastal promenade (Fig. 3b). A building block that seems to be resolved with reinforced concrete, a decision reflecting his fears of the imminent war. This new type, laminar, tapered, slender, which docks at sea like an ocean liner about to be launched (published in volume IV of Le Corbusier's Oeuvre Complete after World War II), may be part of the references of the Pirel- 
li tower (1952-61) designed by Gio Ponti's team. This, in turn, would be the starting point of a media imaginary about this type of skyscraper - always a container of tertiary functions - that Juan Guardiola would reinterpret in the Vistamar tower (1962-65) in Alicante, adapting it to tourist residential use in front of the sea. But before approaching both towers, Pirelli and Vistamar, it is convenient to see the Spanish architectural culture in its reception of the skyscraper.

$$
* * * * *
$$

Le Corbusier visited Madrid in 1928 and gave two lectures at the Residencia de Estudiantes in which the book advanced: Une maison-Un palais (which included the Ville Contemporaine and the Plan Voisin for Paris); months before, the magazine Arquitectura published its Five Points for a 'New Architecture' [08]. In that year, the headquarters of the Compañía Nacional de Teléfonos was under construction, the only building classified by the press as a skyscraper due to its height, and which was designed with a steel grid "calculated in accordance with the mandatory standards of New York" [09]. However, it would take a quarter of a century for these milestones to be proposed in Spain.

In 1955 the Revista Nacional de Arquitectura opened one of its issues with the title "Skyscraper Deficit", where part of Alberto Sartoris' chapter of the Enciclopedia de la Nueva Arquitectura was reproduced, in which he said: "The 'skyscrapers' are not still the cathedrals of our days. [...] The North American skyscraper currently has nothing but the merit of its height" [10]. This text served as an introduction to the Sección Crítica with the theme of "Skyscrapers in Spain" [11]. Faced with the full rejection of M. Fisac and the doubts of C. De Miguel, the opinions of Muñoz Monasterio and Gutiérrez Soto pointed out the necessary distinction between skyscrapers and tall buildings. The controversy was aroused by the visual impact caused by the already completed España Building (1948-53) and the Madrid Tower under construction (1954-60), the latter supported by the municipality (Fig. 4); in addition to offices, these properties included high-end homes.

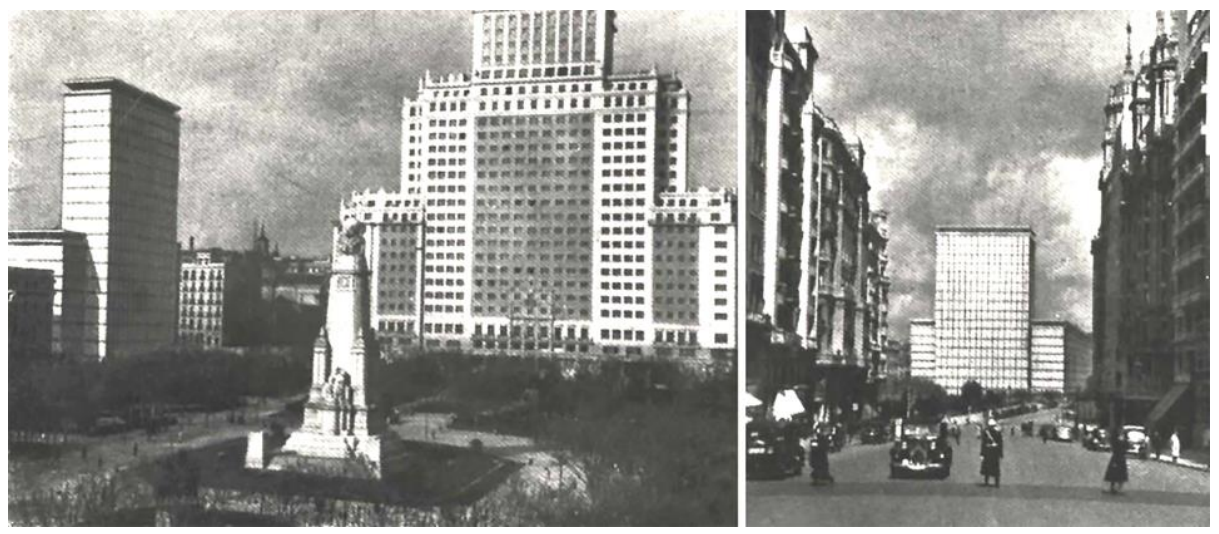

Fig. 4. Madrid, 1950s. (a) Photograph of the Plaza de España with the España building (right) and a photomontage of the Madrid tower (left) (b) Photomontage of the Madrid Tower, Municipal Urban Planning Department [11, p. 41]. 
Although agreement was not possible in that debate on the convenience or not of skyscrapers, a certain type of towers was making its way into some Spanish cities. This new horizon would define both the Apartments in Madrid (1954-57) by Carvajal and García de Castro, and the Valencia Tower (1957-59) by Gutiérrez Soto, which would be published in the pages of the refounded Arquitectura; these skyscrapers were not isolated, but used low podium forms that occupied the entire site, adapting their volume to the continuity of the plans of the urban block. It was evident that the magazine was betting on the innovation of development in height, both by reproducing Spanish skyscrapers, and by echoing the international events that increased the relevance of the subject: between 1959 and 1962 the competition for the Peugeot skyscraper and the Pirelli skyscraper appeared, both above $100 \mathrm{~m}$. Thus, at the beginning of the 1960s, official professional critics did not reject these buildings, on the contrary: they disseminated them as an image of progress in the Western world to which Spain was rejoining.

\section{The Pirelli skyscraper in Milan: 1952-1961, Gio Ponti's Team}

The Pirelli tower has been one of the most prominent symbol of Milan's identity, the wealthiest of Italian city and the "moral capital" of the country, that had built its fortune on factories, real estate development, design and fashion. It is no longer the highest building of the city but, among the skyscrapers, is still the most refined.

Pirelli tower was raised on the eastern edge of the failed Milan's Business District. This last was an extensive building land, between the Stazione Centrale and the Stazione Porta Garibaldi, available after the former railway had been taken off, where a CBD (Central Business District) would have been raised in the ' $50 \mathrm{~s}$.

Several planning mistakes and an indecisiveness attitude by the municipality of Milan didn't succeeded in stopping the random clustering of office buildings while the directional and financial functions were gathering in the historical center that has always been the real 'downtown' of Milan [12].

The Pirelli company undertook to build a new headquarters in 1952. Engineers Valtolina and Loria [13] drafted up a proposal in which one 77 meter-high tower with 22 floors was supposed to be placed southwest of the Stazione Centrale, on a small block owned by Pirelli, known as La Brusada, where the former backyard factory built by the company in 1888 laid.

In 1952 Gio Ponti was appointed as official designer of the new building; at those times, he was a well-known and prominent architect, director of Domus magazine; besides he had just finished the second Montecatini office building in largo la Foppa (nowadays USA embassy), considered the biggest architectural work of his middle age, and the emblematic arrival point of all the issues that open the second age of his architectural work [14].

Considering the Pirelli simply a building is reductive; the distinguishing form, and the 127 meter high that made it the tallest building in Milan up to 2010, makes it an 
icon and a heap of expressive power with a deep structural significance, as the shape is a strong interpretation of how architecture is put together.

The target was to design a freestanding building that set unusual relationships with urban tissue, different from the traditional ones based on the alignment to the streets and the boundaries of the block. In the issue n. 49 of Edilizia Moderna magazine, Ponti stated that the "ideal office building" should have not constrained the ground's shape but be free to take a rational and independent floor layout [15].

By one hand, this attitude fits the ideology of modernism according to which the buildings have not to be flushed with the street grid; on the other hand, it is countertrend if compared to Milanese modernism and Milan's School. In the same period, Ernest Nathan Rogers argued that the architectural design should establish root on the relationship with the context and its historical layering. E.N. Rogers, charismatic intellectual leader of BBPR, conceived architecture as creative energy through which the designers could establish a net of relationship which, in turns, surrounded people, history and the environment. The Velasca tower transforms the tectonics into a particular syntax with a calibrated contrast between the giant order of the everted ribs and the more minute one of the window openings, close in scale to those of the surrounding urban fabric.

On several occasions [16] the Pirelli skyscraper has been compared with the Velasca tower designed by BBPR (1959). Although the two buildings are typologically different (not coincidentally we are speaking of tower and skyscraper) they have assumed an emerging role towards the urban fabric becoming primary facts able to symbolically represent the identity of modern architecture Milanese. The Velasca tower is a metaphorical representation of history, a museum machine transformed into a tertiary residential building whose reasons are understandable with reason and knowledge [17].

The Pirelli skyscraper is an aesthetic object of great refinement understandable, as such, through an act of love, mainly perceptive, towards architecture, understood as the quintessence of beauty (Fig. 5). In the Pirelli skyscraper, the syntax is less distinctive than in the Velasca tower, since the building is surrounded by a curtain wall which, like a skin stretched over a mechanical body, helps to define the "finished" shape dear to Ponti.

The latter responds to the Ponti's axiom of "architecture as a crystal" [18]: in fact in the Pirelli, instead of the rectangular plan common in tall office buildings, such as the nearby Galfa tower by M. Bega (1956-59), the plan has a lenticular pattern, with a slightly polygonal profile, concluded with two triangular tapering, whose vertex is broken by a void. Ponti argued that "architecture must achieve a definite closed form which can not grow in height or width, since this would be the contrary of the form $[\ldots]$ architecture is not made by the volume but by the form, the closed, finished, unmodificable form" [19].

The volume therefore has a deep "carving" at the ends, that with the transparency of the façade should have turned the building into a source of light that would have stressed its lightness. Due to structural constraints, Ponti gave away the purity of the vertical cuts by accepting the 'cursed balconies' which collaborated in the static resistance. 


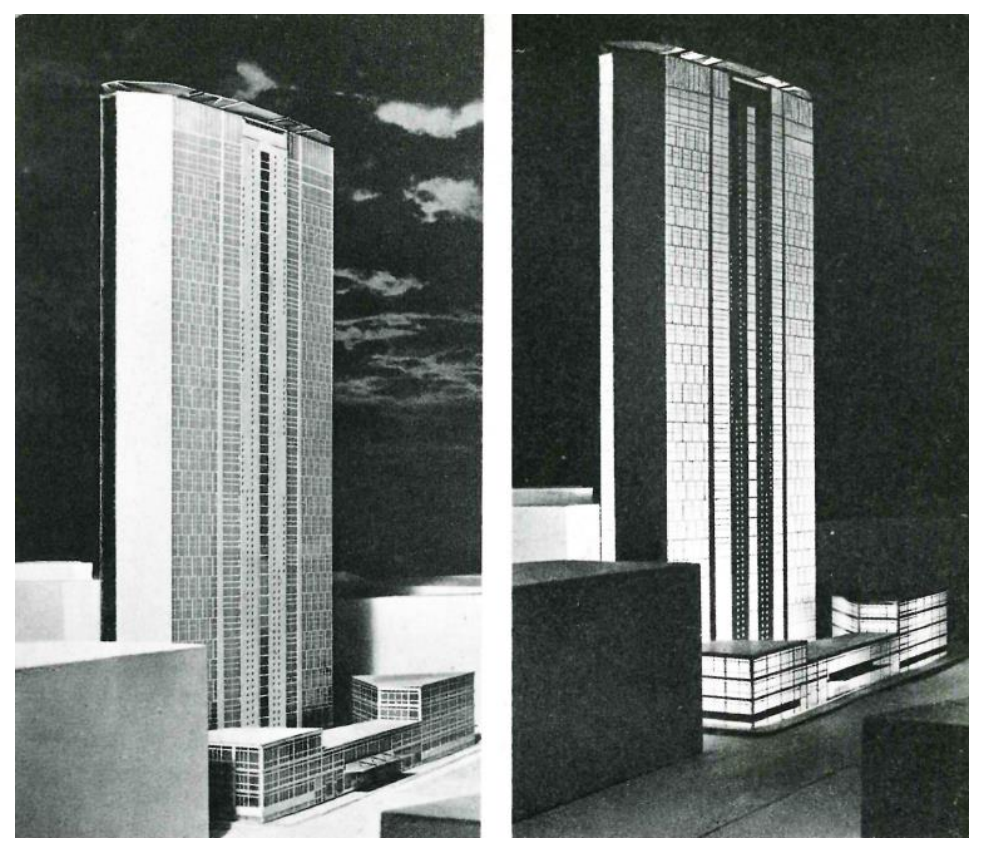

Fig. 5. Views of the model of the first project design by Gio Ponti, 1952 (Domus 1956 and Revista Nacional de Arquitectura 1958 [33, p. 26]).

For the same reason he was forced to modify, compared to the initial project, also the curtain walls keeping the isotropic order of the supporting grid but accepting a lower degree of transparency of the outer skin. In any case the curtain wall works in counterpoint with the 'strenght' of the structural system visibly expressed by the monolithic triangular section pillars that shape the ends of the building (Fig. 6). The two engineers Pier Luigi Nervi and Arturo Danusso (the latter deals with the load tests on a 1:15 scale model) gave a fundamental contribution concentrating the static system into a few and clear elements; in addition to the aforementioned pillars, the skyscraper is supported and withstands the winds thanks to four deep beam that allow very wide bays approximately of 24 meters [13].

Nervi's contribution was decisive in containing the thickness of the reinforced concrete slab to $75 \mathrm{~cm}$ thanks to prestressing and ribbing techniques. The designer pursued flexible and modifiable spaces by means of large bays and movable walls; the flexibility of the interior space is one of the main themes of Ponti's architecture widely experimented, for example, in the houses, including that of the same architect built a little later in via Dezza (1955-57). Even the offices of Pirelli, although they are workplaces, are 'domestic' spaces whose measurements are based on a $95 \mathrm{~cm}$ square module due to the size of the typical desk and the use space around it. This module also defines the rhythm of the facade. From this standpoint, Ponti's design thinking is close to the idea of continuity typical of Milanese modernity expressed above all by Carlo De Carli [20]. 

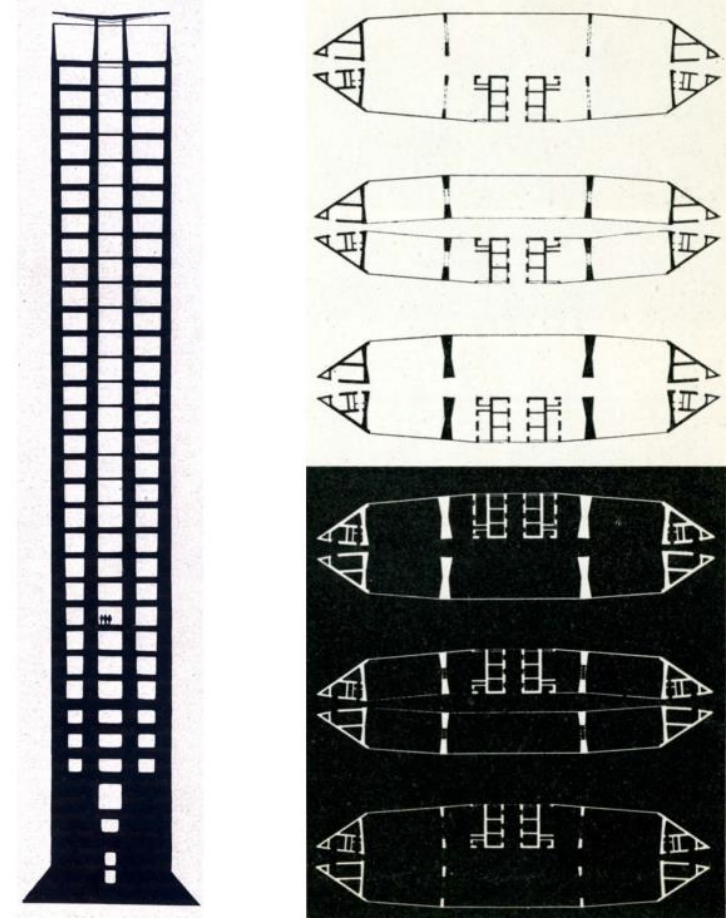

Fig. 6. The graphic slogans: section and plan of the Pirelli skyscraper (Domus 1956 and Revista Nacional de Arquitectura 1958 [33, pp. 19, 23]).

Unlike other skyscrapers, Pirelli sorted out the relationship with the ground dematerializing the base, towards the large square in front of the Stazione Centrale, into a sloping plate under which the auditorium and the mechanographic center are located. It raises the building very little, leading to the representative entrance of the building and establishing hierarchies at the level of the ground and giving greater importance to the east side of the building.

For what concerns the conclusion of the building in height, on the thirtieth floor there are the offices of the presidency and the CEO, while above them there is a double-height panoramic terrace that allows a contemplative and remote relationship with the city. Which could recall that detachment from the magmatic urban chaos evoked by Le Corbusier in Beisteguì attic and in plan Obus, as well as the quartier of La Marina.

The roof is closed by a reinforced concrete canopy detached from the envelope to emphasize its lightness. Also, in this case there were changes compared to the initial project as Nervi introduced reinforced concrete beams, of undeniable plastic beauty, to support the trolley for cleaning the facades. This operation subtracted the lighting envisaged by Ponti coming from under the shelter, reducing the poetic charge he imagined. 
There are really many images of Pirelli some of them were drawn to be a 'graphic slogan' as the section that "highlights the tapering of the pillars as the load on the slab decreases" [21]. But the most relevant is the building itself who is still able to give us an unforgettable image of Milan's identity.

\section{The Vistamar tower in Alicante: 1962-1965, Juan Guardiola Gaya}

In 1957 Juan Guardiola Gaya (1927-2005) graduated from Barcelona School of Architecture. In 1959 he arrived in Alicante on the advice of urban planner Perpiñá Sebriá, with whom he was collaborating on the project for the AZCA business center in Madrid, which he had won in a national competition (Fig. 7a). Guardiola secures the commission of planning the north coast of the municipality of Alicante. By 1962 he had made the first drawings of the Vistamar skyscraper, on the seafront, with a height of 36 storeys and $96.5 \mathrm{~m}$. With only five years in the profession, he designed this audacious structure when, simultaneously, he was planning the 30-storey Coblanca-1 tower, the first residential skyscraper in the nearby city of Benidorm [22].

Since 1959, and during the early 60's, Guardiola designed the First Polygon of San Juan beach [23], destined for a tourist development, on a flat site facing the sea (Fig. $7 b)$. He uses a wide plot $(260 \times 180 \mathrm{~m})$, designed with isolated blocks and differentiated volumes, influenced by the Dutch urban planning of Bakema and Van der Broek from previous years. This approach of freeform built elements extends from the north to the southeast where, when encountering a more irregular terrain, it adopts a more organic road network adapted to the site contours, reaching up to the small beach of La Albufereta. In the area between it and the city of Alicante, the coast becomes rugged as the mountain range of San Julián abruptly descends to the sea (Fig. 8b).

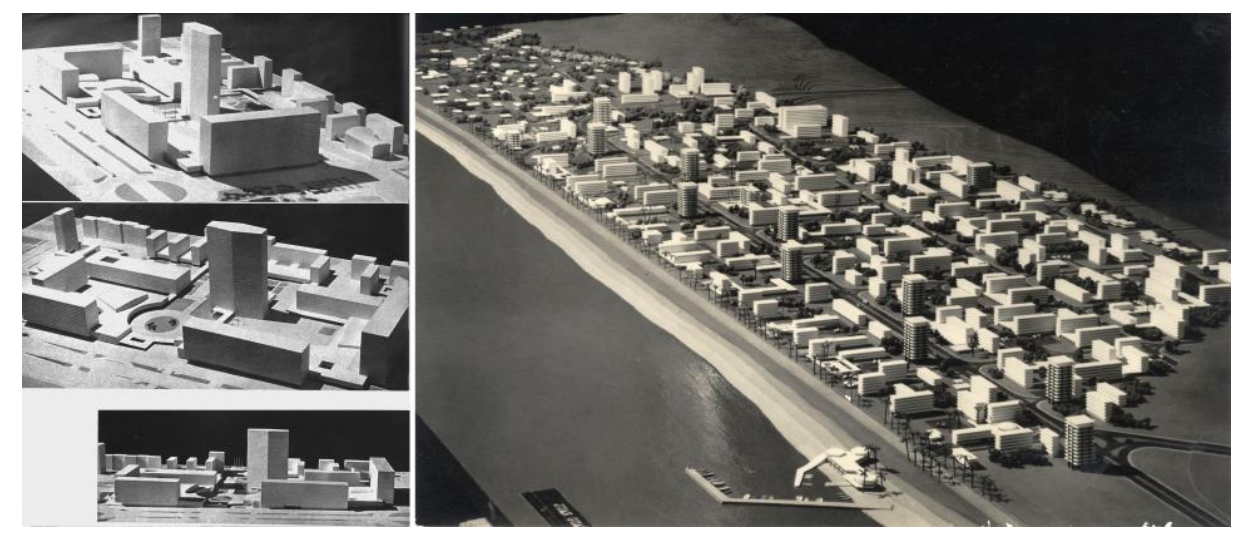

Fig. 7. (a): Full page of the Cuadernos de Arquitectura magazine with three images of the model of the AZCA business center, Madrid, 1955, Perpiñá, ( ) Arxiu Històric del Col·legi d'Arquitectes de Catalunya [24, p.6(38)]. (b): Model of the partial plan for the First Polygon of San Juan beach (Alicante), 1959, J. Guardiola [23]. 
Instead of avoiding construction in this steep area, the architect maintains his principles of open-grain building: the exempted blocks are arranged on the steep slope of the mountain range while proposing a buildable area three times that considered for the rest of the planned areas [25] to make its expensive development economically viable. This leads to the contradiction of providing the most rugged area with more density, which is how the urban complex of La Albufereta arises, where the contrast of the blocks against the rocky mass stands out (Fig. 9). Most of the buildings bear Guardiola's signature. In the area where the mountains step back from the sea, there are three levels of built forms that, taking advantage of the steep slope, are placed in a staggered manner to allow views of the sea from all the buildings. The coastal road passes behind the first line of the building at about $20 \mathrm{~m}$ above sea level, so access to the buildings is through the upper floor or an intermediate level, as in the Vistamar tower. In the narrowest area, to the south, where the mountains descend almost vertically, the architect draws a serpentine linear block adapting to the undulating edge of the mountain. In the urban plan, this 20-storey block reached the city of Alicante [25] (Fig. 8), an approach reminiscent of Le Corbusier's plan for the city of Algiers from 1930-42 (Fig. 3). Coincidentally or not, the promoters of the Alicante complex were Pied Noirs from Algeria [26].

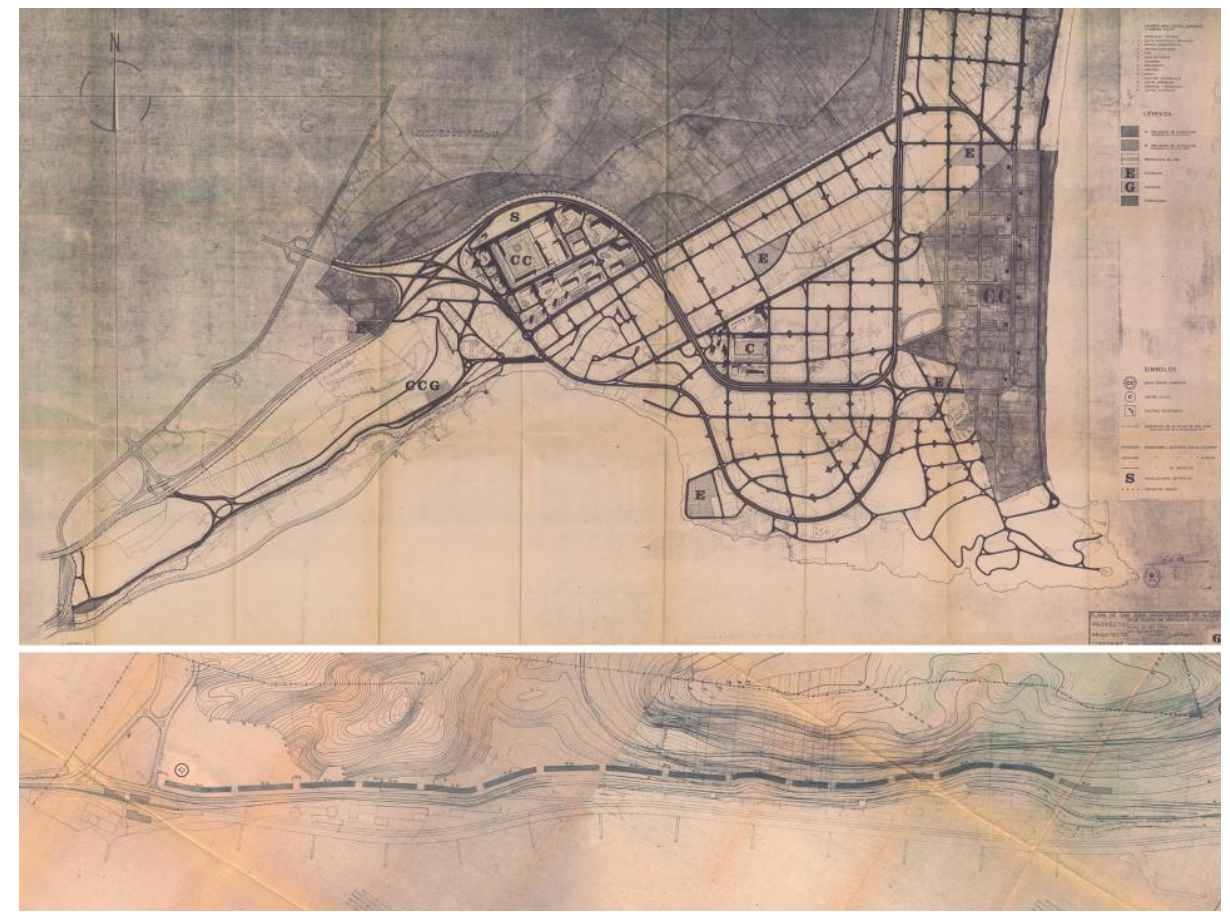

Fig. 8. (a): General plan of the planning of the north coast of Alicante, 1971, J. Guardiola [27]. (b): Detail of the large linear block planned in the area of the Sierra de San Julián, 1963, J. Guardiola [25]. 
The complex was developed from the east (La Albufereta beach) to the west (Alicante) and the architect was shaping his projects on successive models. Despite the permitted density, at the beginning, the buildings were arranged with a certain balance, but, given the success of the promotion, as we advance in time (and towards the southwest) the buildings interfere with each other (Fig. 9). From the first model, one can already see the arrangement of a singular tower as an urban landmark of the complex, defined from three factors: its outstanding height, its slenderness (as a counterpoint to the mass of the mountain range) and its striking shape.

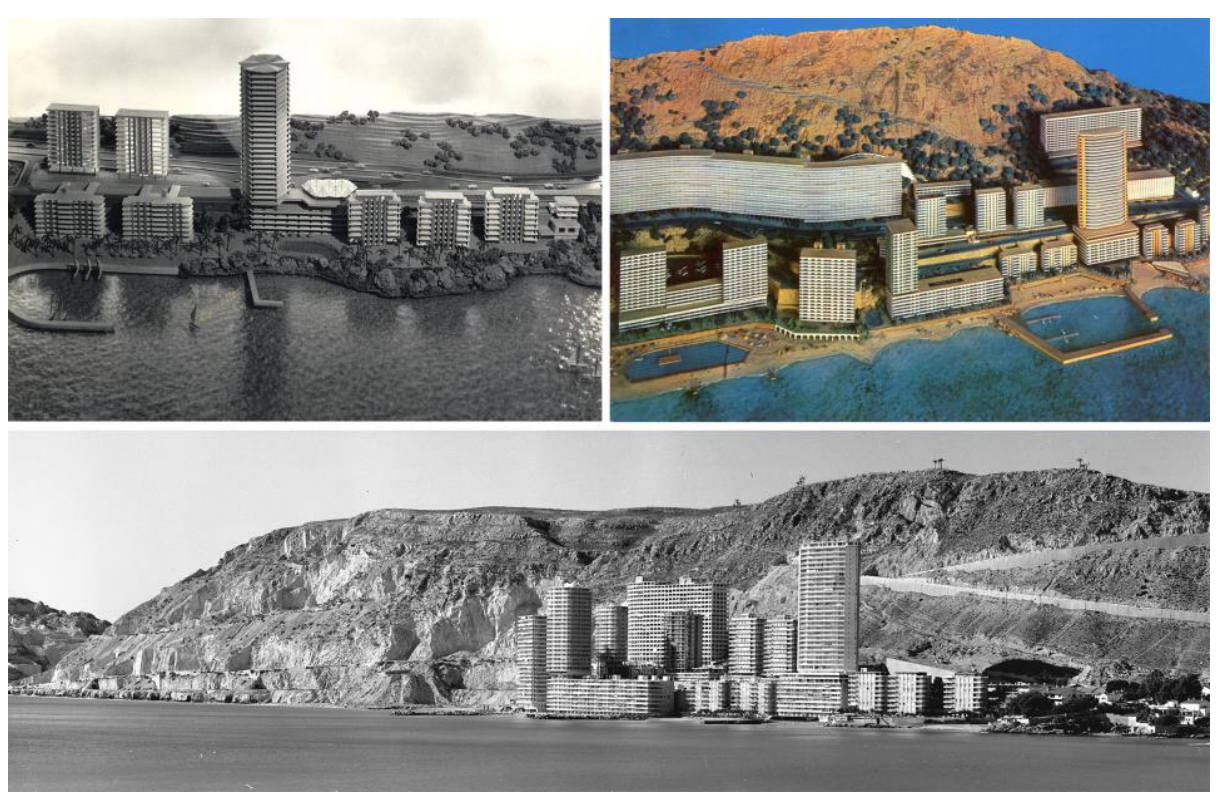

Fig. 9. Urban complex of La Albufereta, 1960-1968, J. Guardiola. (a): First model with hexagonal tower, ca. 1961 [28]. (b): Almost final model of the tourist complex, ca. 1964 [28] and [29, p. 115]. (c): Photo of the almost finished arrangement, ca. 1968. Source: Historical Archive of the Town Hall, Alicante; Photographic collection Eugenio Bañón Rodes [30].

The first proposal for the tower presented a hexagonal envelope with a terrace surrounding its entire perimeter (Fig. 9a). But, when its final preliminary project is proposed [31] and the project is developed [32], the tower uses an oblong plan with a tapered shape. Its direct reference is the Pirelli skyscraper of the team led by Gio Ponti (Figs. 5, 6), projected a few years before and published twice (in project and built) in the magazine of the Official College of Architects of Madrid [33, 34]. Guardiola had been trained (simultaneously with his studies) in the office of the Barcelona architect Francesc Mitjans who, Guardiola commented, had the Italian architect as one of his teachers. It is therefore not surprising that, while Guardiola used this reference, Mitjans in collaboration with S. Balcells also resorted to it when designing, two years later, the Banco Atlántico (now the headquarters of Banco Sabadell) in Barcelona in 
1965 (Fig. 18). If Mitjans used the lenticular plan for an office building repeating, to a certain extent, the compositional and structural schemes of the Italian model, Guardiola proposes an exercise in typological translation, by adapting the schemes of an office building with a curtain wall facade to a tourist sector residential building.

This approach entails several difficulties: a) adapting the elements of the residential typology to a composition on a larger scale than that provided by the unit elements of the dwellings, which are repeated on all floors; b) the tower had to adapt to an extremely rugged orography that had nothing to do with the sites of the Ponti and Mitjans towers; c) it was necessary to resolve the formal conditions of the tapered floor plan in the residential typology, more compartmentalised and with tighter dimensions than those of the administrative typology; and d) all this had to be subject to a realistic promotion with relatively conventional techniques: those available in the construction sector in the Spain of desarrollismo, a period that coincides with that of the miracolo economico in Italy.
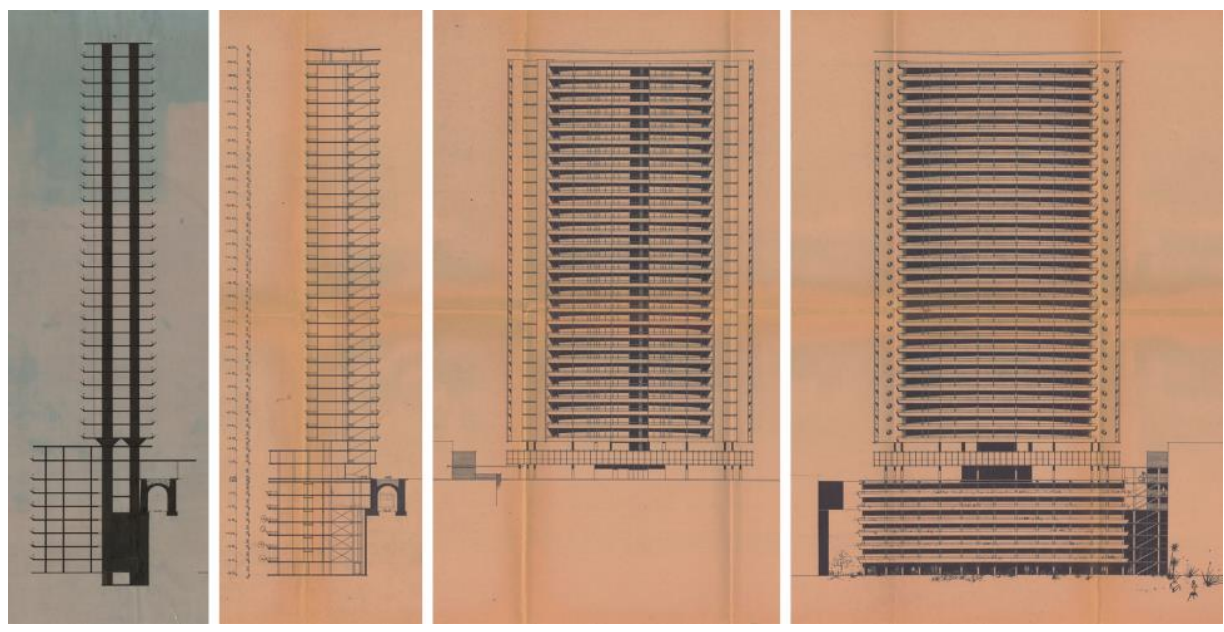

Fig. 10. Vistamar tower, J. Guardiola. Section of the preliminary draft of 1962 [31] and section and elevations (back and front over the sea) of the 1963 project [32]. The train tunnel can be seen right next to the building, note how the lattice is not depicted in the rear elevation.

The composition of the elevations of the Vistamar tower is indebted to the Milanese composition whose scheme Guardiola repeats. On the two screened facades, each pair of Pirelli solid walls that frame the large glass fronts is transformed into a tandem of side panels (front and back) built with the same orange-ochre facing brick that is present throughout the complex (Figs. 10, 11, 13). Then, on the facade facing the sea, the curtain wall of the Italian skyscraper is replaced by a continuous terrace that unifies the image of the houses (Fig. 11), while, in the rear elevation, said curtain wall is reinterpreted by means of a large lattice surface covering almost the entire façade (Fig. 13). If Mitjans in his Banco Atlántico will resume the vertical tripartite division of the Pirelli curtain wall, Guardiola, under the residential conditions, acts more 
freely. And thus, on the maritime façade, the terraced body expresses the logical superposition of the floors, determined by the horizontal sheets of the slabs, without defining any clear vertical separation element (Figs. 10, 11).
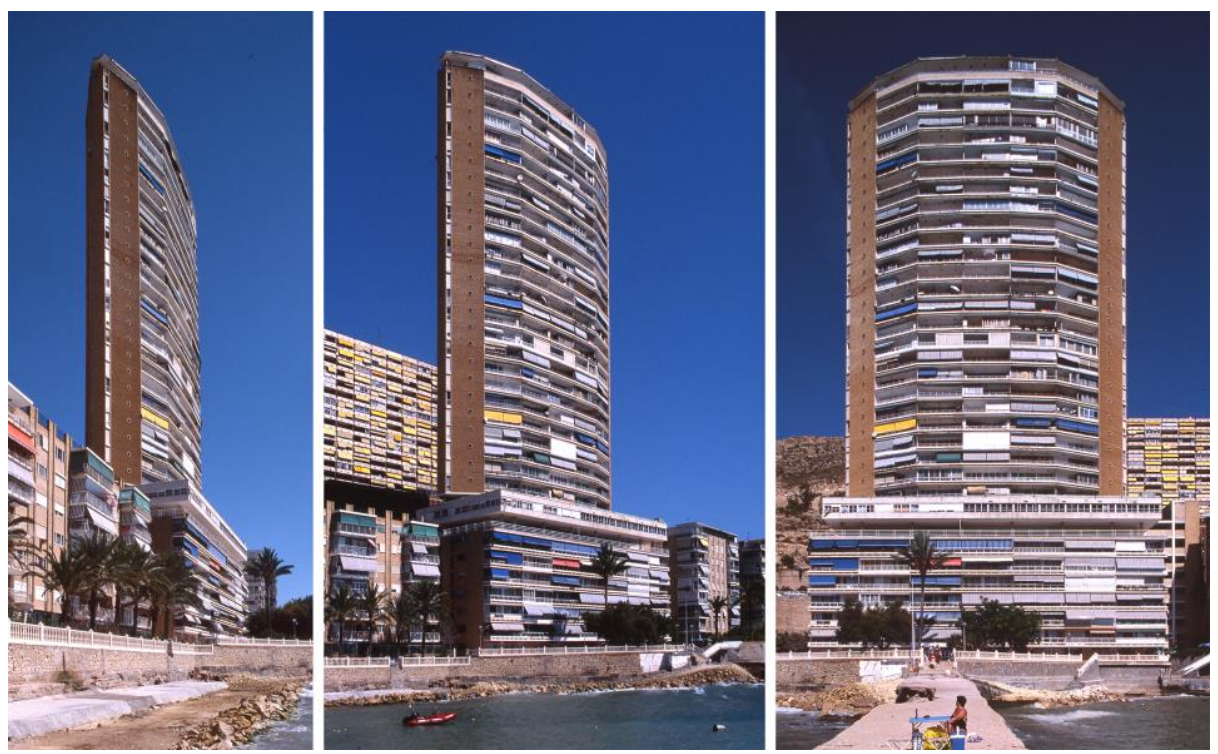

Fig. 11. Different views of the Vistamar tower from the sea: two foreshortening views and front view (Authors, ca. 1996).

Although Guardiola does not include the structural approach of the three large prestressed concrete bays of Ponti, he does repeat the scheme of transverse frames with strong tapering forms at their ends, with only two support crosswalls clearly drawn in the section of the preliminary project, but using a structure of steel columns and beams (Fig. 10). In the 1963 project, the screens are replaced by two metal pillars located $1.5 \mathrm{~m}$ apart, which together act as crosswalls that stiffen the skeleton against wind stress (Figs. 12a, 14, 15a). The goalpost structure, logically, are made to coincide with the separation walls of the houses (by means of $7.5 \mathrm{~m}$ spans), configuring a partition into five modules that cannot be seen on the facades.

At the extremes of the plan, the last goalpost structure is reinforced by additional pillars located perpendicular to it ( $1.5 \mathrm{~m}$ from the outer pillar), shortening the flight at the end faces and bracing the tower in the longitudinal direction of the block (Fig. 12a). However, in the executed solution, the proposal is to insert two columns by goalpost structure, reducing the flights at their ends and the span of the first and last goalpost structure. Finally, separate pillars are added to the two fronts of the floor, avoiding the strong overhang of the previous solutions (Figs. 12b, 15b, 18).

The outline of the floor plan resembles that of a boat. The architect himself nicknamed his own tower design "el barco" - 'the ship'-, and that is how it is popularly known. Its location, just in front of the coastline, links the Guardiola building with Le 
Corbusier's prototype with a lenticular plan that he projected in 1938 for the Naval Zone of the city of Algiers (Fig. 3), antecedent to the Milan skyscraper project. A relevant difference between the Algerian project and the Alicante project, in addition to its greater dimension, is that, while Le Corbusier faces his project's head towards the sea, Guardiola places 'the ship' parallel to the coast. Both arrangements are logical, since in Algiers the tower is located at a projecting point of the land allowing views of the sea on both sides, while the Vistamar tower is implanted in a narrow strip between the road and the coastline, looking for the panoramic views of the Mediterranean.
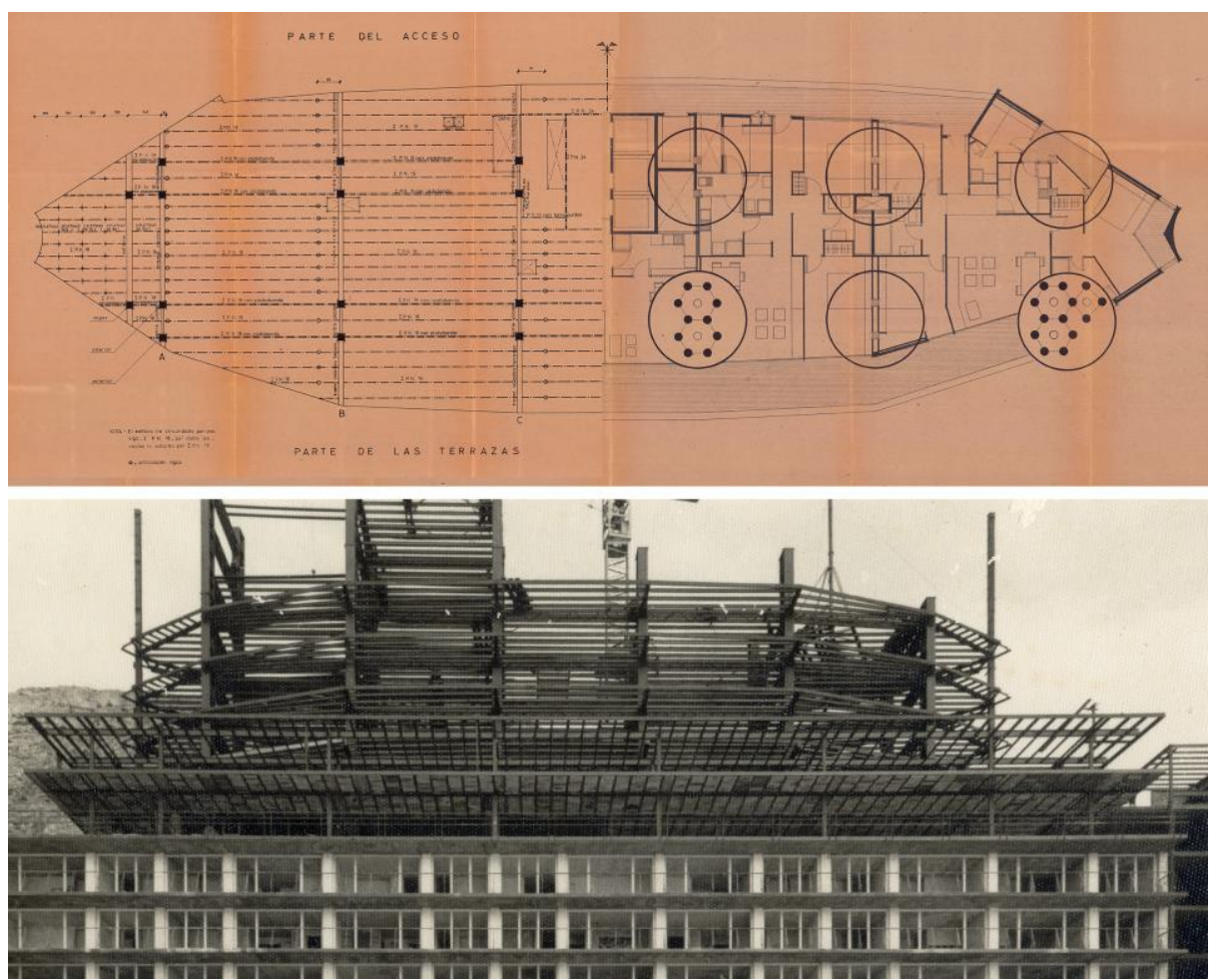

Fig. 12. (a): Torre Vistamar, structure: plan with view of the slab (left) and diagram of the piling foundation (right) [32]. (b) photo of the beginning of the tower structure under construction [28].

The prototype of the Swiss master does not have a front and rear façade as in the Guardiola building, but rather two symmetrical and equivalent facades resolved with sun-protective brise-soleils. On the contrary, Guardiola, on the facade to the sea, uses the oversailing terraces as a large parasol for the houses and as a shelter from the summer sun. Meanwhile, the rear façade is shown more neutral and abstract with an immense plan $(22 \times 65 \mathrm{~m})$ of precast white concrete pieces that generate a uniform interwoven textile-like covering (designed together with the artist Miguel Losán) as a 
reinterpretation of the great Algerian brise-soleil. This surface with relief becomes a giant sculpture that formally unifies the facade of the access galleries to the houses (Figs. 13, 17a).

It must be remembered that it is not the first time that this type of singular tower appears in the professional biography of Juan Guardiola. In the 1955 proposal made by Perpiñá Sebriá for the block of the AZCA center in Madrid, the skyscraper with two convex facades already appeared as a vertical landmark in the center of the commercial and office complex (Fig. 7).
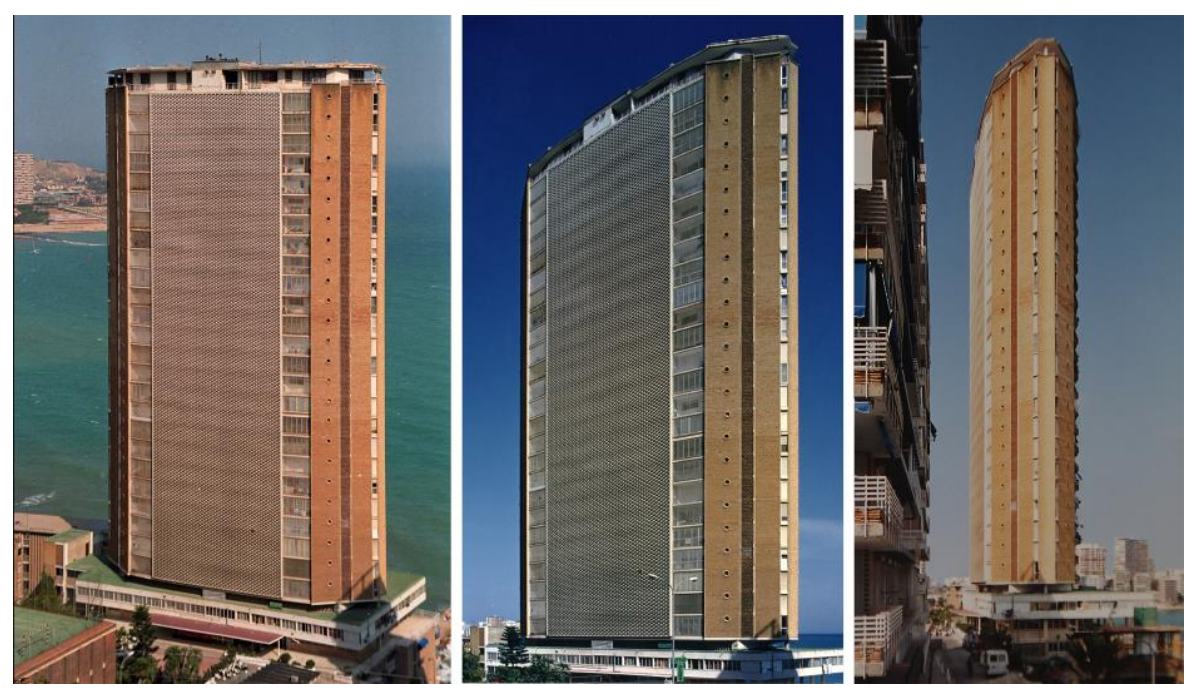

Fig. 13. Three views of the rear façade (facing the road) of the Vistamar tower with the large lattice (Authors, ca. 1996).

The Vistamar tower - a residential laminar skyscraper - must resolve, like all the buildings in the La Albufereta tourist complex, its implantation in an abrupt orography. The access to the same is gained from the road that crosses, parallel to the sea, the entire complex; however, the building is founded seven stories below, right on the coastline (Figs. 10,11). The aerodynamic tower, with its rear façade positioned tight to the retaining wall of the mountain, could not start at shore level, so Guardiola had to provide a solution that modified that of the reference types that, both in the case of Le Corbusier as in Ponti's, spring directly from the ground itself.

The tower, therefore, rises above the level of the road, resting on a large parallelepiped that, as a base, generates the horizontal platform necessary for the skyscraper to emerge with its expressive profile. The static and heavy prism, with an orthogonal envelope, supports the slender, light and lenticular volume of broken contours. A white horizontal prism, on one floor and dedicated to a restaurant, acts as a hinge between both elements: the aerial tower and the prismatic base (Figs. 10, 11). This hinge is supported on the pilotis of the steel structure grid, between which the sea horizon can be contemplated, only interrupted by the entrance hall (Fig. 16). 
The podium, being attached to the mountain, had by its nature the disadvantage of lacking a rear façade, so the typological choice of the dwellings was not immediate. Guardiola resorted to a very frequent type of touristic building design: that of the exterior rear gallery that gives access to the apartments, although, in this case, the said corridor faces the solid of the mountain. This difficulty was solved with the resource of expanding the width of the gallery that is ventilated at its extremes (Fig. 14).

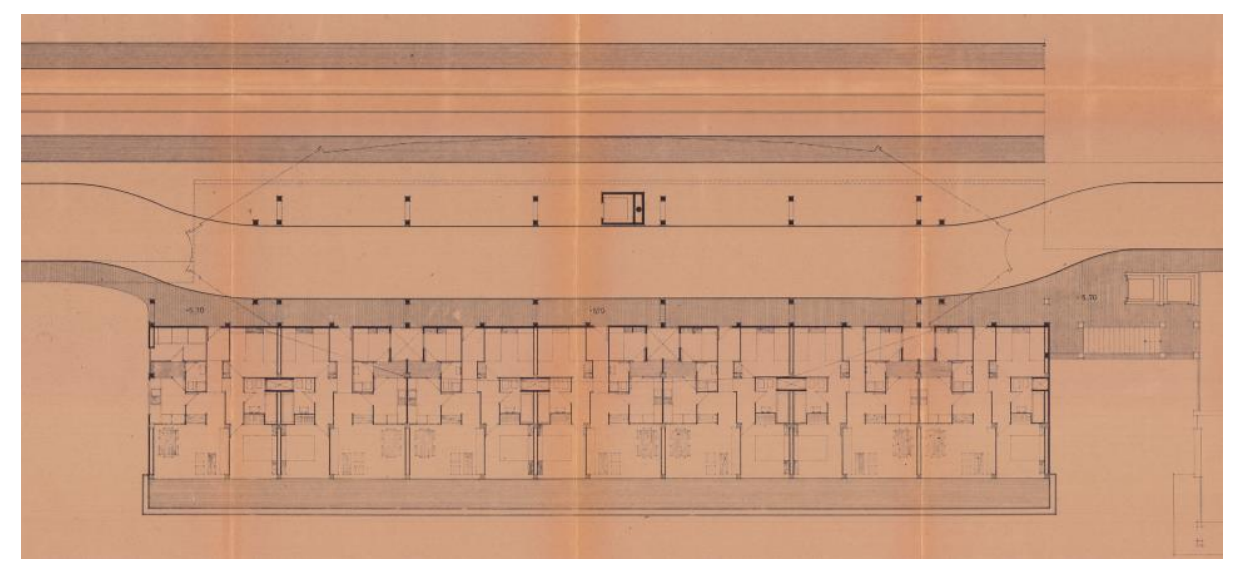

Fig. 14. Standard plan of the podium volume with the pedestrian path under the tower (its outline projection is visible) and the passage of the train tunnel just behind the building [32].

Although there are almost non-existent examples of this type of project block with a rear access gallery in social housing from the $50 \mathrm{~s}$ and $60 \mathrm{~s}$ in this peripheral geography, the relationship between the types of touristic residences of seasonal use and those of social housing with minimum space standards is evident. Suffice to note paradigmatic examples of the modern movement, such as those designed by W. Gropius for the siedlungen Dammerstock (1927, Karlsruhe) and Siemensstadt (1929, Berlin) or the high-rise block of the Haselhorst neighborhood (1929, Spandau) where this system of access to homes is employed despite year-round living, residents subjected to much colder climates than the Mediterranean.

The standard plan of the Vistamar tower resolves in a more canonical way the access to the houses through an elevated pedestrian street. Its distribution responds, in its central part (except for the logical variants imposed by the tapered outline of the floor plan), to the residential type that the architect has experimented with during these years of designing tourist residential buildings with an exterior corridor as means of access. From the vertical communications core (staircase - with four elevators - positioned on the axis of symmetry, but shifted backwards, as in the Pirelli) that allows entry to a reduced apartment (with 1 bedroom), the rear gallery starts towards both sides giving access to two minimally dimensioned apartments (with 2 bedrooms) and, at the ends, to two houses with larger area (3 bedrooms) (Fig. 15). Significantly, all of these habitats, despite their compressed dimensions, incorporate a 
room for domestic service, which reveals the middle class aspirations to which the promotion is directed.

Undoubtedly, the fact of considering this type of skyscraper as residential reinterpreting the volume and profile of the office prototype - is the most important contribution of this tower, a translation not without difficulties when coupling types of minimal dwellings to the tapered outline of the floor plan. In fact, while in the three central apartments the orthogonality of the structural grid and the almost perpendicular edge of the curved façade allow it to fit without difficulty, in the units at the ends (with an almost triangular perimeter) the encounters of the partitions with the double twist of the elevation, absorbing them in the distribution of some of the interior pieces, is a question that the architect solves with skill. If the resulting irregular spaces are analyzed, we discover that its design indeed works well for domestic use (Fig. 15b).
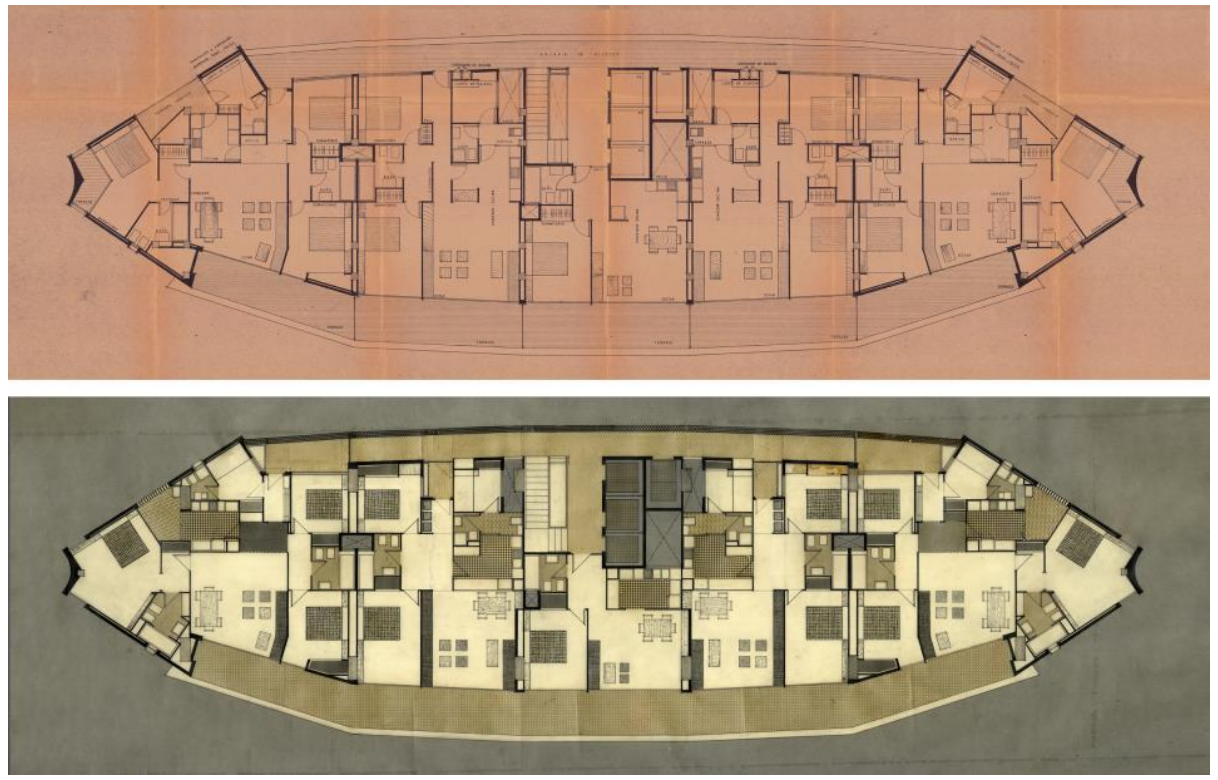

Fig. 15. (a) Two solutions of the standard plan of the Vistamar tower. 1963 project with the replacement of screens by pairs of pillars [32]. (b) Solution executed in 1965 with two pillars per goalpost and smaller overhangs, extreme goalpost structure with less span (without cantilever) and independent pillars to the end apexes [30]

With the Vistamar tower, Guardiola manages for the first time to generate an urban landmark in an exnovo context that follows the principles of the CIAM of well-lit buildings, the founding premise of modern movement architecture. This functionalist approach is repeated in the 1965 La Rotonda tourist complex on San Juan beach with a 15-storey square tower that marks out the new urban landscape of a planning conceived to serve the car (which recalls the proposal of A. Libera of 1933 for Castel- 
fusano and is linked to that of A. Bonet of 1961 for the Mar Menor), as Guardiola himself reasoned in the memory of his urban plan of 1959 [23]. Around 1972, he repeated this approach in the urban plan to widen the Levante beach in Benidorm (the tourist metropolis with more residential and hotel skyscrapers from the 70s in Europe) through the Benidorm tower, a 26-storey structure with a stepped profile. The scale of the interventions helps to achieve urban landmark, but, really, it is the expressive resolution of the volume and the silhouette of each of these residential skyscrapers each with its figure cut out against its corresponding background - that is the fundamental factor that makes each tower stand out and achieve uniqueness within an environment comprising tall buildings, quite literally redrawing the 'skyline' [51, pp. 115, $118,124,142]$.
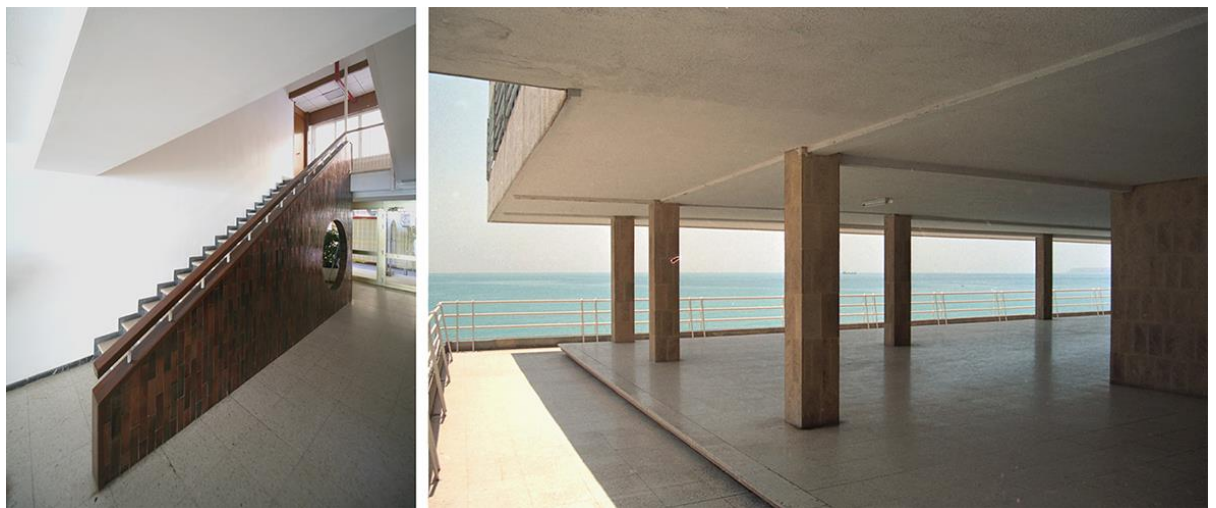

Fig. 16. Details of the access floor. (a): Staircase of the hall covered in glazed ceramic tiles. (b): Open floor as a viewpoint to the ocean horizon (Authors, 1996-2008).

Perhaps one of the great merits of Juan Guardiola in the Vistamar tower is the realism and pragmatism with which he composes, without concessions, the resounding volume of this skyscraper, using media and cultured references in the context of a local economy eager for short-term profits. Thus he arrives at the solution of a powerful urban vertical landmark based on a conventional goalpost structure and an abstract formal language that reinterprets vernacular issues such as the wall and the porch. All together, he achieves a new and contemporary image by resorting to physical materials — brick - and architectural elements - terraces and lattices - that reinterpret constructive systems and ways of living in the Mediterranean (Figs. 11, 13, 16, 17). 

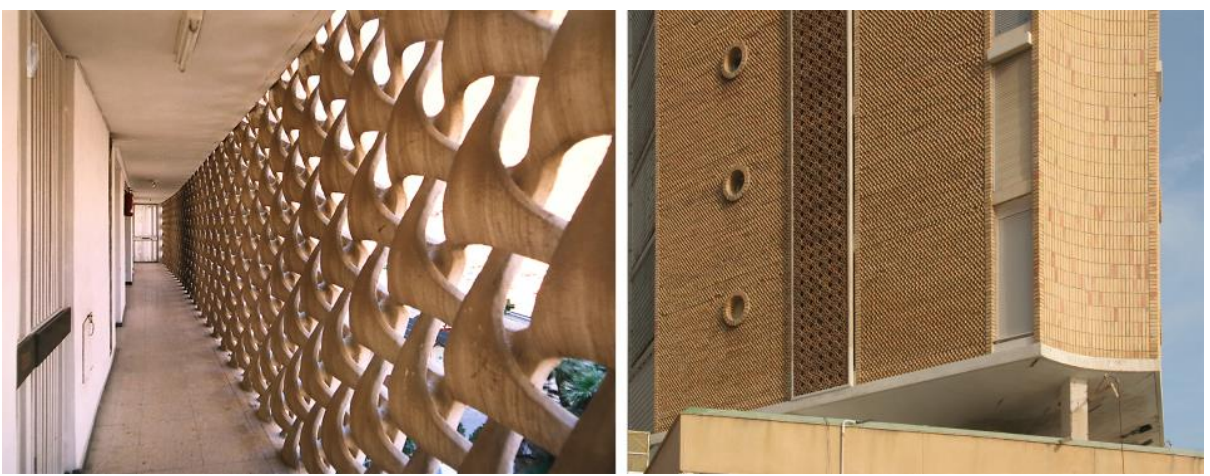

Fig. 17. (a): Access gallery with the lattice designed by J. Guardiola in collaboration with M. Losán. (b): Detail of the lattice from the outside and inside. Detail of the brick treatment in the end walls (Authors, 1996-2008).

\section{The skyscraper and the tower as uniqueness of the skyline: Vistamar versus Pirelli}

In the epigraphs of this text we have used the term 'skyscraper' to name the Pirelli in Milan and 'tower' for the Vistamar in Alicante; tower is an older word (Greek and Latin), while skyscraper is more recent (North American). The latter seemed to be reserved only for tall buildings (which required an elevator) destined for offices, but the emergence of residential skyscrapers since the 1930s in Chicago and New York [35], generalised around 1960, and their current proliferation, makes them interchangeable words today: the Pirelli tower and the Vistamar skyscraper. In all these 'high-rise buildings' there is such a concentration of users (in any of the uses: tertiary or residential) that a direct dependence is established with the means of transport: vertical landmark and horizontal arteries (subway, train, highway) are in direct dependence. The Pirelli 'grattacielo' stands next to the metro station Stazione Centrale (train station) and the Vistamar 'torre' includes the suburban train tunnel in its section (figs. 10,14). Well planned in its prestressed concrete structure against the wind's thrusts (which increase with height, since the structure works in cantilever), the Pirelli presents a natural resistance when airflow passes, tangentially bordering its aerodynamic contour by opposing its solid volume, while it depends on transversal buttresses when the wind hits its surface. The response of the project is to define a laminar skyscraper, with a floor plan measurement of a ratio of 1 to almost 4 and a section of the order of 1 to 7 (a figure that is doubled at the end). But this ingenious skeleton disappears under the glass skin that hides it. Perhaps part of the secret of the 'beauty' of this architectural type and urban landmark resides in this extreme stylised slenderness, which is reinforced by its isolation and distance from neighbouring buildings. These proportions would not be reached by any of the cases that would emulate it later conforming the new family that arises after the Pirelli, only the Vistamar Tower comes close to reaching the elegance of the Pirelli (Fig. 18). 

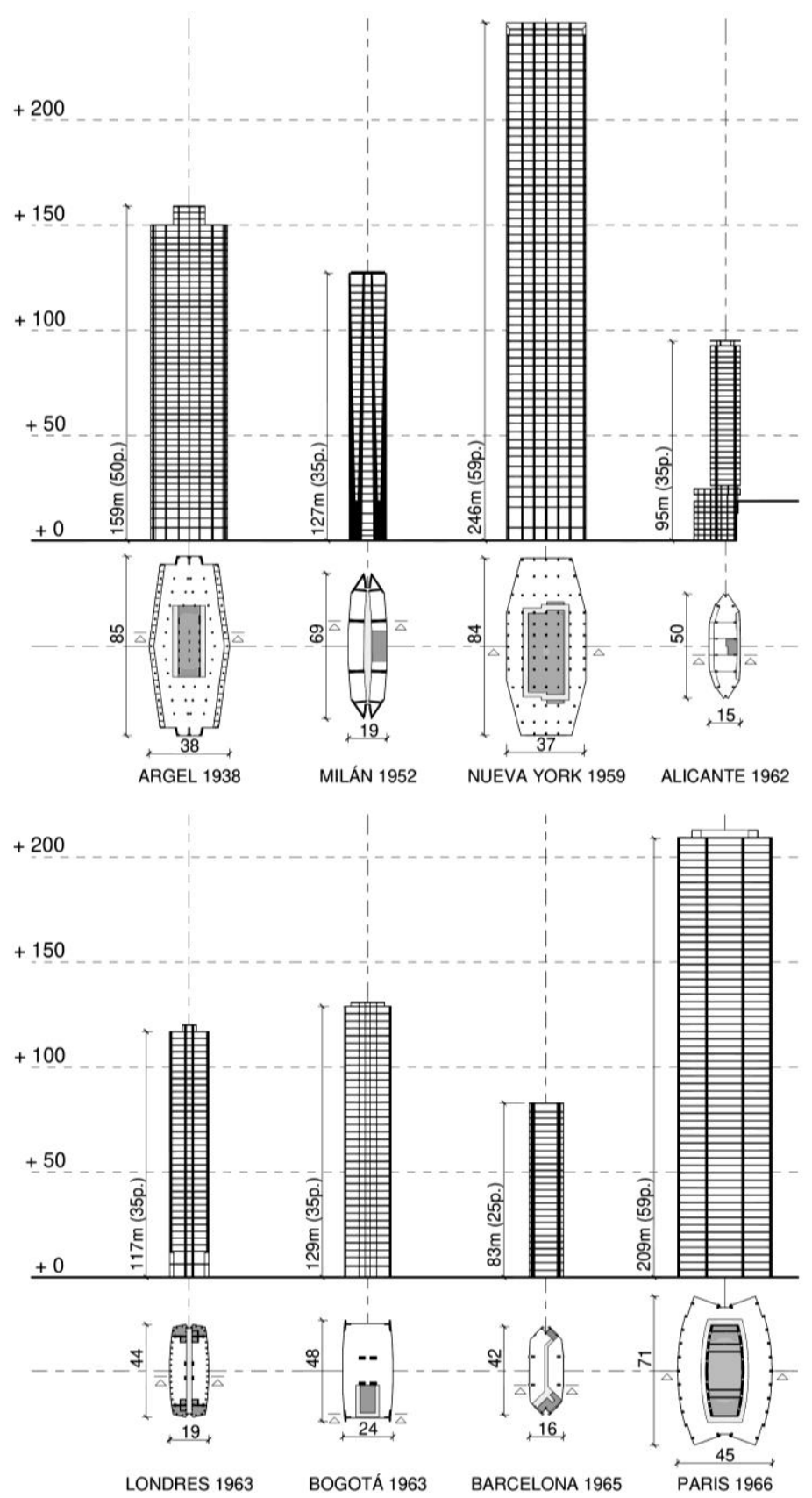

Fig. 18. Scheme of plans and sections of the skyscraper after the Pirelli (Authors, 2020). (Top): La Marina (Algiers, 1938), Pirelli (Milán, 1951), Panam (1959, Nueva York) and Vistamar (1962, Alicante). (Bottom): Centre Point (1963, Londres), Avianca (1963, Bogotá), Banco Atlántico (1965, Barcelona) and Montparnasse (1966, París). 
The Pirelli tower (reminiscent of Le Corbusier's prototype in Algiers), is the milestone that sets a starting point for an innovative imaginary in the typology of skyscrapers from its diffusion through the mass media of the time. It is a concrete and precise figure: that of a tower with a lenticular plan, a laminar volume and a slender section at the limit of calculation, wrapped in a 'curtain wall' of latest generation glass that defines it as an elegant icon, reflecting the lights (day and night) everywhere, and affirming the definition of its author of "L'architettura è un cristallo" [18]. The power of this silhouette highlighted on the low profile of the Milan skyline, made the main European capitals hurry to replicate this lighthouse [36]. It is no coincidence that London, Barcelona and Paris emulated this skyscraper with speed: Centre Point (1963-67), Banco Atlántico (1965-69) and Montaparnasse Tower (1966-73), respectively, are evidence of this media and metropolitan success; all of them corporate headquarters or open-plan offices that adopted this image as a symbol of the technological progress that would soon transcend the architectural sphere; but the last skyscraper received popular rejection for the speculative nature. However, in the case of Pirelli, both photography and cinema helped to spread it and turn it into a stage for fashion [37]. These means helped to fix the Pirellone - as the inhabitants of Milan call their skyscraper - as a sign of identity of the Milanese with their city (Fig. 19a).
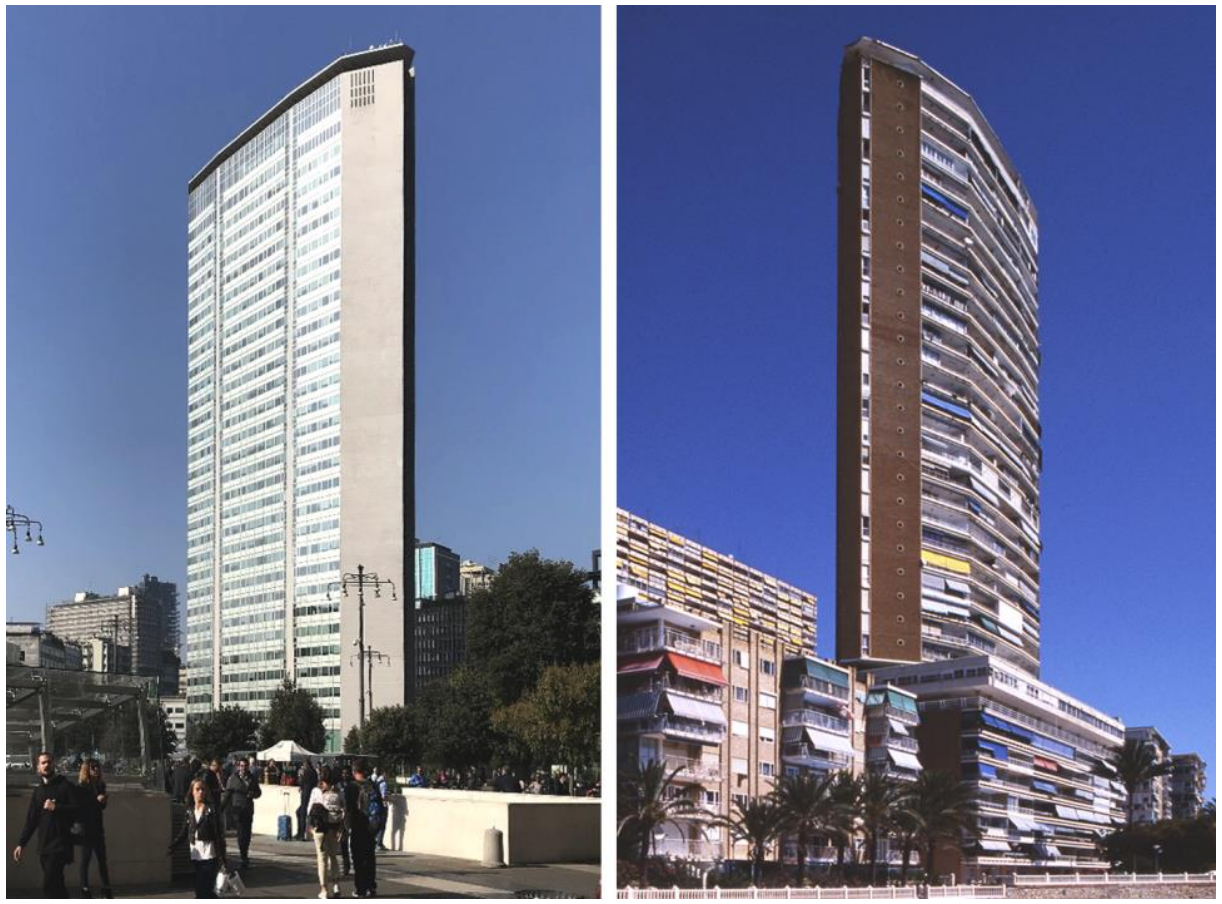

Fig. 19. (a): Pirelli ‘tower’, Milán, 1952-1961, de G. Ponti, G. Valtolina, P.L. Nervi, A. Fornaroli, A. Rosselli, G. Renaldi and E. Dell'Orto. (b): Vistamar 'skyscraper', Alicante, 19621965, Juan Guardiola. (Authors, 2012 and 1996). 
The previous series of skyscrapers would be extended with others around the world; in fact, the Panam (today's MetLife Building) in New York (1959-63) and the Avianca in Bogotá (1963-69) (Fig. 18) should be added, both of which, like their counterparts, are office blocks. To this list we must add the Vistamar Tower in Alicante (1962-65) (Fig. 19b), which reinterprets the Pirelli in a residential key, using traditional and Mediterranean materials to transpose its iconic image from a peripheral geography in the midst of the tourist boom that Spain experienced since its opening to Europe in 1957, as a sign of the admiration and fluid dialogue between both shores of the Mare Nostrum.

\section{References}

1. Sullivan, L.H.: Autobiografía de una idea. Infinito, Buenos Aires (1961).

2. Peisch, M.L.: The Chicago School of Architecture. Phaidon Press, Bristol (1964).

3. Tafuri, M.; Dal Co, F.: Arquitectura Contemporánea 2. Aguilar de Ediciones, Madrid (1989).

4. Watson, P.: Historia Intelectual del siglo XX. Crítica, Barcelona (2007).

5. Abbott, J.: The Harper Establishment or How the Story Books Dre Made. Harper\&Brothers, New York (1855).

6. Koolhaas, R.: Delirio de Nueva York. Gustavo Gili, Barcelona (2004)

7. Le Corbusier: Cuando las catedrales eran blancas. Poseidón, Barcelona (1979).

8. Le Corbusier: Cinco Puntos sobre una Nueva Arquitectura. Arquitectura 107, 78-84 (1928).

9. Cárdenas, I.: El edificio de la Compañía Telefónica Nacional de España en Madrid. Arquitectura 106, 42-46 (1928).

10. Sartoris, A.: Déficit del Rascacielos. Revista Nacional de Arquitectura 158, 1-2 (1955).

11. Sección Crítica: Rascacielos en España. Revista Nacional de Arquitectura 158, 29-44 (1955).

12. Pracchi, A., Grandi, M.: Milano: guida all'architettura moderna. Zanichelli, Bologna (1980).

13. Cevini, P.: Grattacielo Pirelli. La Nuova Italia Scientifica. Firenze (1996).

14. Irace, F.: Gio Ponti. La casa all'italiana. 2nd edn. Electa, Milano (1995).

15. Ponti, G.: Considerazione sugli edifici per uffici. Edilizia Moderna 49(12) 11-18 (1952).

16. Torres Cueco, J.: El valor de la imagen en la edificación in altura. Quadernos TC 17 (2), 33-39 (1993).

17. Bonfanti, E.; Porta, M. Città, museo e architettura. Il gruppo BBPR nella cultura architettonica italiana. 1932-1970. Milano, 2nd edition Hoepli (2009).

18. Ponti, G.: Amate l'architettura. L'architettura è un cristallo. Società Editrice Vitali e Ghianda, Genova (1957).

19. Ponti, G.: Opere in corso nel nuovo studio professionale Ponti, Fornaroli, Rosselli. Aria d'Italia. Espressione di Gio Ponti. VIII. Reprint Milano. Electa. (1954/2011).

20. De Carli, C.: Architettura spazio primario. Hoepli, Milano (1982).

21. Ponti, L.: Gio Ponti e Milano. Guida alle architetture 1820-1970. Quodlibet. Macerata. (2019). 
22. Martínez-Medina, A., Oliva Meyer, J.: Vértigo de altura: elogio de un rascacielos. La torre Coblanca-1, Juan Guardiola Gaya, Benidorm, 1963-1965. In: Actas del II Congreso Nacional Pioneros de la Arquitectura Moderna Española. Aprender de una obra. vol. 2, pp. 426-437. Fundación Alejandro de la Sota \& Ministerio de Fomento, Madrid (2015).

23. Guardiola Gaya, J.: Plan Parcial de ordenación de la Playa de San Juan (Primer Polígono). Historical Archive of the Town Hall, Alicante (1959).

24. Perpiñà Sebrià, A.: Anteproyecto de urbanización en la avenida del General Franco, Madrid. Cuadernos de Arquitectura, 22, 5-10 (1955).

25. Guardiola Gaya, J.: Plan Parcial del Tercer Polígono de la Playa de San Juan. Historical Archive of the Town Hall, Alicante (1963).

26. Sempere Souvannavoung, D.: Los "Pied Noirs" en Alicante, las migraciones inducidas por la descolonización. Universidad de Alicante, Alicante (1997). pp. 59-60.

27. Guardiola Gaya, J.: Plan Parcial de ordenación de los Sectores 2, 12 y 13 de la Playa de San Juan (Alicante). Historical Archive of the Town Hall, Alicante (1971).

28. Guardiola Gaya, J.: Professional Archive, Alicante (1959-2005).

29. Aa.Vv.: La arquitectura del sol_Sunland architecture. Colegios Oficiales de Arquitectos of Cataluña, Comunidad Valenciana, Islas Baleares, Murcia, Almería, Granada, Málaga and Canarias, Barcelona (2002).

30. Alicante Town Hall: Historical Archive. Photographic collection Eugenio Bañón Rodes. Alicante.

31. Guardiola Gaya, J.: Anteproyecto de inmueble residencial en La Albufereta. Professional Archive of Juan Guardiola Gaya, Alicante (1962).

32. Guardiola Gaya, J.: Proyecto de apartamentos en La Albufereta. Professional Archive of Juan Guardiola Gaya, Alicante (1963).

33. Ponti, Valtolina, Dell'Orto, Fornaroli, Roselli, Nervi, Danusso: Edificio Pirelli en Milán. Revista Nacional de Arquitectura, 199, 19-27 (1958).

34. Ponti, Fornarolli, Roselli, Nervi: Edificio Pirelli en Milán. Arquitectura, 42, 30-33 (1962).

35. Aa.Vv.: Il Grattacielo. Edilizia Moderna 80, 1-108 (1963).

36. Aa.Vv.: Proceso al Grattacielo. Hinterland 2 (1), 1-86 (1978).

37. Pia Fontana, M.; Mayorga, M.; Roa, M.: Fotografía y construcción de "Imágenes de Ciudad". Tres edificios en altura: Pirelli (Milán), Atlántico (Barcelona) y Avianca (Bogotá). ART 1 (1), 48-68 (2018). 